\title{
Risk of Transmission and Knowledge Gap for Novel Coronavirus Disease 2019 (Covid-19) in Addis Ababa: Risk Estimation and Control Strategies
}

Getnet Bogale Begashaw ( $\square$ getnetbogale145@gmail.com )

Wollo University https://orcid.org/0000-0002-7107-8388

Yordanos Yohannes

Addis Ababa University - Selale Campus

Research article

Keywords: Addis Ababa, Covid-19, Knowledge Gap, Risk Activities

Posted Date: May 8th, 2020

DOI: https://doi.org/10.21203/rs.3.rs-26771/v1

License: (c) (1) This work is licensed under a Creative Commons Attribution 4.0 International License.

Read Full License 


\title{
Risk of Transmission and Knowledge Gap for Novel Coronavirus Disease 2019 (Covid-19) in Addis Ababa: Risk Estimation and Control Strategies
}

\author{
Getnet Bogale Begashaw ${ }^{1 *}$ : $\quad$ Yordanos Berihun Yohannes $^{2}$ \\ ${ }^{1}$ Wollo University, Dessie, Ethiopia \\ ${ }^{2}$ Salale University, Fitche, Oromiya, Ethiopia \\ Correspondence should be addressed to Getnet Bogale Begashaw getnetbogale145@gmail.com
}

\section{Abstract}

Background: A novel coronavirus disease 2019 is pandemic infectious disease. It is neither SARS nor influenza; rather it is a zoonotic virus that can be transmitted to humans. COVID-19 was emerged at the end of 2019 in China in Wuhan, the capital of Hubei China. Physical contact and respiratory routs are the two most important well established routs of transmission of the virus. This study is aimed to evaluate knowledge gap and risk activities against Covid-19 in Addis Ababa. Methods: The study used a primary data collected from 431 individuals with analysis of descriptive statistics and multivariate binary logistic regression. Explanatory variables practicing health care service, age, sex, family size, working place, lock down, safe working environment, use transportation, contacting density population, health status and flight history; and knowledge gap and carefulness is response variable at 5\% level of significance. Results: In this work practicing health care service \& physical distance, safe working environment and Contacting density population are statistically significant predictors in describing risk transmission of Covid-19. Intercept ( $\mathrm{OR}=1.429$, 95\% CI: 1.199, 1.659), Practicing health care service \& Physical Distance (OR=6.885, 95\% CI: 6.765, 7.005), Working Place $(\mathrm{OR}=1.206,95 \% \mathrm{CI}: 0.961,1.451)$ and Safe working environment $(\mathrm{OR}=4.013,95 \% \mathrm{CI}$ : $3.768,4.258$ ) were factors significantly associated with increased risk of Covid-19 transmission. Conclusions: To control disease transmission in Addis Ababa we need to encourage inhabitants to practice health care service \& physical distance, to work their jobs at home and preparing national guidelines to safe working environment and usage transportation.

Keywords: Addis Ababa, Covid-19, Knowledge Gap, Risk Activities 


\section{Introduction}

\subsection{Background}

Novel Coronavirus disease 2019 (COVID-19) is an infectious disease caused by severe acute respiratory syndrome coronavirus 2 (SARS-CoV-2) [1]. COVID-19 is accidental global health burden especially for developing countries in terms of death and economic cost. The disease was first identified in 2019 in Wuhan, the capital of Hubei China, and has since spread globally, resulting in the 2019-20 coronavirus pandemic [2]. The virus is transmitted from infected person to susceptible human via respiratory system droplet, contact, and fomites. According to CDC, 2020 report infected humans shows disease symptoms like fever, breathlessness, cough, it may take 2-14 days for a person to notice symptoms after infection, but muscle pain, sputum production, diarrhea, and sore throat are less common [3], [16].

COVID-19 infection has four distinct stages [4]. The first stage is importing by test positive person who have a travel history aboard to virus infected countries the second stage is when the local transmission of virus from infected persons to susceptible person. The third stage is stage of virus transmission across community to a person who hasn't travel history or exposed to infected person. The fourth stage is stage of the infection where it takes on the form of an epidemic. [13]

While according to the WHO report more than $80 \%$ of Covid-19 positive patients can recover, around $14 \%$ get severe disease, causing breathlessness and pneumonia and about $5 \%$ critical disease and the failure of more than one organ 2\% will get in fatal death. COVID-19 virus have four life cycle steps such as; attachment and entry, replicas protein expression, replication and transcription, and assembly and release [5]. Until the preparation of this article (21 April 2020), more than 2,501,920 cases of COVID-19 have been reported in more than two hundred ten countries and territories, resulting in over 171,741 deaths but more than 658,956 people have recovered from this deadly virus [6].

The COVID-19 infection has created an enormous health challenge worldwide. The major continents affected by this disease were Europe, America and Asia. Until April 28, 2020 Africa confirmed 33,627 new cases, 10,226 recovered and 1,476 death against Covid-19. Ethiopia is the second most populous nation in Africa, next to Nigeria. According to WHO alert Ethiopia will be one of the seriously affected countries in Africa. Since first evidence of the COVID-19 
pandemic was reported in Ethiopia in March 14, 2020 in Addis Ababa COVID-19 has claimed the lives of 124 (Apr 27, 2020) [6].

COVID-19 is transmitted from infected human to susceptible human through fluids in the respiratory system, fomites, physical contact, uncontrolled sneezing and cough such as mucus. Less aligned emphasis has been given to the COVID-19 in Ethiopia. Citizens have unique social attachment (greeting, work place, religious culture and holidays, transportation, etc) are serious risk for transmission of COVID-19 [7], [8], [12].

In order to reduce the number of deaths caused by COVID-19, it is better to supply free awareness creation schedule and close physical contact. Closing physical contact is controlling strategy help to block the replication of disease to community. Poor hand hygiene practice, overcrowding, and close physical contacts like hand shaking contributes for the fast spread of the virus with in very short period of time. Restricting mobility of individuals within the border and across borders is believed to be key in preventing transmission [8].

\subsection{Statement of the Problem}

Ethiopia shares land borders with 5 countries (highly attacked by COVID-19) Sudan, Somalia, Djibouti, Eritrea and Kenya. Proportions of tested individuals are near zero compared to the total population of Ethiopia. This is an indication the current number of Covid-19 positives in the country could be a lot more had all the population been tested. A limited diagnostic center and quarantine places will leads to increase this number. Since Addis Ababa is capital city number of foreigners, tourists, national meeting and transportations are centralized. Inhabitants have a wide range of variability across economical, educational and consciousness in capital Addis Ababa.

Although most of the residents in the capital are considered to have access to awareness programs, knowledge of the infection, better access to health care and opportunity to obtain sanitary materials such as detergents, currently Addis Ababa is reeling from unprecedented spread of the virus. Recently in Addis Ababa the number of bars and restaurants (averagely in 150 feet (45 meters) and counted at least 30 bars; one after another on both sides.), hotels, khat and addiction house, commercial sex workers, proletariat, transportation, radically increases throughout the capital city. Students play football and others in community. The population density is estimated to be near 5,165 individuals per square kilometer available. It is critical to protect health care workers and the community from virus transmission and create a safe 
working environment. However, individuals comeback to their home after higher rate of unsafe physical contact. This all discovers Covid-19 positive patients will be extremely increased (outbreak). Hereof, this article was considering the above research gap into account and evaluates the risk activities and knowledge gap of community in Addis Ababa, Ethiopia about Covid-19.

\subsection{Objectives}

\subsubsection{General Objective}

The main objective of this study was to analyze Risk Transmission and Knowledge Gap for Novel Coronavirus Disease 2019 (Covid-19) in Addis Ababa, Ethiopia.

\subsubsection{Specific Objective}

This study is aimed to address the following specific objectives:

- To identify social and economy emergency problems associated with covid-19 in community.

- To evaluate the knowledge gap and carelessness action taken by community regarding to covid-19.

- To assess the attitudes of actions that can save lives now and avert large scale crisis from Covid-19.

- To assess the prevention measures followed by the people.

\section{Method}

The COVID-19 pandemic has impact of both social and economic. It remains one of the leading causes of mortality around the world. Nigeria confirms first case in Sub-Saharan Africa Jan 28, 2020 and the disease has been spread throughout the continent including Ethiopia.

\subsection{Data Description}

\subsubsection{Data Source and Study Area}

The data used in this study is obtained from community live in Addis Ababa. There are more than 116 Woreda in 10 Kifle Ketema. The population of Addis Ababa is estimated to be 6 million. The data is taken from peoples living in selected Woreda. Data was collected by face to face interview with the selected 431 respondents with the help of questionnaire. 


\subsubsection{Study Population}

All COVID-19 positive patients are illegible (fulfill inclusive criteria) for this study. The study sample will be selected by using stratified random sampling technique. All susceptible groups including both male and female will be target population (more than four million).

\subsubsection{Variables in the Study}

Table 1: Variables in the Study

\begin{tabular}{|c|c|c|c|}
\hline No. & Variable & Variable Description & Code (if any) \\
\hline 1. & Degree of awareness & $\begin{array}{l}\text { Level of awareness (knowledge gap) on Covid- } \\
19 \text { transmission method and carefulness }\end{array}$ & $\begin{array}{l}0=\text { Poor } \\
1=\text { Enough }\end{array}$ \\
\hline 2. & Practicing health care service & $\begin{array}{l}\text { Practicing health care service and physical } \\
\text { distance for Covid-19 }\end{array}$ & $\begin{array}{l}0=\text { No } \\
1=\text { Yes }\end{array}$ \\
\hline 3. & Age & Age of respondent & $\begin{array}{l}0=\text { below } 30 \text { years } \\
1=30 \text { and above years }\end{array}$ \\
\hline 4. & Sex & Sex of respondent & $\begin{array}{l}0=\text { male } \\
1=\text { female }\end{array}$ \\
\hline 5. & Family size & Family size of respondent & \begin{tabular}{|ll}
$0=$ below 5 & $(<5)$ \\
$1=$ more than & $5(>=5)$
\end{tabular} \\
\hline 6. & Working Place & Current working place & $\begin{array}{l}0=\text { Home } \\
1=\text { Office }\end{array}$ \\
\hline 7. & Lock down & $\begin{array}{l}\text { Having enough food to stay for at least two } \\
\text { weeks to lock down of mobility }\end{array}$ & $\begin{array}{l}0=\text { No } \\
1=\text { Yes }\end{array}$ \\
\hline 8. & Safe working environment & $\begin{array}{l}\text { Working environment is sever for transmission } \\
\text { of Covid-19 }\end{array}$ & $\begin{array}{l}0=\text { No } \\
1=\text { Yes }\end{array}$ \\
\hline 9. & Use transportation & Using transportation in day to day activities. & $\begin{array}{l}0=\text { No } \\
1=\text { Yes }\end{array}$ \\
\hline 10. & Contacting density population & Rate of contacting density population daily & $\begin{array}{l}0=\text { No } \\
1=\text { Yes }\end{array}$ \\
\hline 11. & Health status & have long live health problem (disease) & $\begin{array}{l}0=\text { No } \\
1=\text { Yes }\end{array}$ \\
\hline 12. & Flight history & Flight history and or getting foreigners & $0=$ No \\
\hline
\end{tabular}




\subsection{Methodology}

Quantitative study method (risk estimation) and descriptive cross sectional research design was applied to assess the risk transmission and knowledge gap for novel Coronavirus Disease 2019 (Covid-19) in Addis Ababa among community. The data analysis was present descriptive statistics (risk activities) of COVID-19.

\subsubsection{Binary Logistic regression}

Logistic regression model is popular statistical tool to model the probability of a certain events as a function of continuous or categorical variables and used when the regressed, the dependent variable or the response variable is categorical binary (dichotomous variable). Binary logistic regression is the form of regression which is used when the dependent variable is dichotomous and the independent variables are of any type. It allows the effects of the explanatory variables (socioeconomic, demographic and health) to be assessed across the logit models and provides estimates of the significance.

Odds ratio (OR): it is usually to describe the chance that the binary response variable leads to a success relative to failure. It is defined to be the ratio of the probability of having enough awareness in Covid-19 infection to the probability of having poor awareness in Covid-19 infection. $\quad[$ Odds ratio $=\mathrm{Pi} /(1-p i)]$.

The natural logarithm of the ratio of pi to (1-pi), gives a linear model in Xi. Specifically:

$$
\operatorname{Logit}[p i(x)]=\log \left(\frac{p i(x)}{1-p i(x)}\right)=\beta o+\beta 1 X i \ldots \ldots \ldots+\beta k X i
$$

Where $p i$ the probability of having enough awareness in Covid-19 infection for the $\mathrm{i}^{\text {th }}$ case, $(1-$ $p i)$ is the probability of having poor awareness in Covid-19 infection for the $\mathrm{i}^{\text {th }}$ case; $\beta o, \beta 1, \ldots \ldots \ldots, \beta k$ are parameters (coefficients).

\subsubsection{Model Assumption}

Assumption of the Logistic Model

1. Logistic regression model does not assume linear relationship between dependent and independent variables. 
2. The dependent variables not normally distributed but assume its distribution is within the range of exponential family of distribution such as normal, Poisson, binomial and gammas.

3. The dependent variables is not homoscedasticity for each level of in dependent variable, which is there is no homogeneity of variance of assumption.

4. Normally distributed error terms are not assumed

5. Logistic regression does not negative that independent continuous variable.

6. Both dependent and independent variables are dichotomous

\subsubsection{Parameter Estimation for Logistic Regression}

Consider the logistic regression model $P\left(x_{i}\right)=\frac{e^{X_{i}^{\prime} \beta}}{1+e^{X_{i}^{\prime} \beta}}$. Since observed values of $\mathrm{Y}$ say, $\mathrm{Y}_{\mathrm{i}}$ 's $(\mathrm{i}=1,2 \ldots \mathrm{n})$ are independently distributed as Bernoulli, the maximum likelihood function of $\mathrm{Y}$ is given by:

$$
L(\beta / y)=\prod_{i=1}^{n} P\left(y_{i} \mid X_{i}^{\prime}\right)=\prod_{i=1}^{n}\left[\frac{e^{X_{i}^{\prime} \beta}}{1+e^{X_{i}^{\prime} \beta}}\right]^{y_{i}}\left[\frac{1}{1+e^{X_{i}^{\prime} \beta}}\right]^{\left(1-y_{i}\right)}
$$

The objective of ML estimation is to get an estimator $\hat{\beta}=\left(\hat{\beta}_{0}, \hat{\beta}_{1}, \hat{\beta}_{2}, \ldots, \hat{\beta}_{k}\right)$ of $\beta$ which maximizes the likelihood function expressed in the above equation. Since the likelihood equation is non- linear in the parameters, the Newton-Raphson iterative maximum likelihood estimation method that expresses $\hat{\beta}$ at the $(u+1)^{\text {th }}$ cycle of the iteration is given as:

$$
\hat{\beta}_{u+1}=\hat{\beta}_{u}+\left(X^{\prime} \hat{W}_{u}\right)^{-1} X R_{u}
$$

where $\mathrm{u}=0,1,2,3, \ldots$ and $\hat{W}$ is a diagonal matrix with its diagonal elements $p \hat{i}(1-p \hat{i})$ i.e. $\hat{W}=\operatorname{diag}[p i(1-p i)]=\operatorname{cov}(y)$. Finally, $\hat{\beta}$ is the maximum likelihood estimator of $\beta$ with residual $R=p_{i}-\hat{p}$ (Collet, 1991: Greene, 1991). Newton's method usually converges to the maximum of the log - likelihood in just a few iteration unless the data are especially badly conditioned (Greene, 1991). 


\subsubsection{Assessment of Model Adequacy}

After the model is fitted the next important step is checking the model adequacy. There are several steps involved in assessing the appropriateness, adequacy and usefulness of the model. First, the overall goodness of fit of the model is tested. Second, the importance of each of the explanatory variables is assessed by carrying out statistical tests of the significance of the coefficients.

\section{Results}

\subsection{Results of Descriptive Statistics}

Table 2 presents summary statistics of the distribution of Level of awareness (knowledge gap) on Covid-19 transmission method and carefulness by different factors in the study area. From the total number of respondents participated in the study was 431, $230(53.4 \%)$ have poor awareness and the remaining 201 (46.6\%). The result reveals that from the total number of $230(53.4 \%)$ who have not enough awareness about transmission of Covid-19 about 110 (47.8) don't practice health care service and physical distance in their day to day activities.

Table 2: Summary statistics of factors that are assumed to associate with Level of awareness (knowledge gap) on Covid-19 transmission method and carefulness in Addis Ababa.

\begin{tabular}{|l|l|l|l|l|}
\hline \multirow{2}{*}{ Covariate } & \multirow{2}{*}{ Category } & \multicolumn{2}{|c|}{$\begin{array}{c}\text { Level of awareness about transmission of Covid-19 } \\
\text { (from human-to-human) and carefulness }\end{array}$} & \multirow{2}{*}{ Total (\%) } \\
\cline { 3 - 4 } & & Poor & Enough & \\
\hline \multirow{2}{*}{$\begin{array}{l}\text { Practicing health care } \\
\text { service \& Physical Distance }\end{array}$} & No & $110(47.8)$ & $107(53.2 \%)$ & $217(50.3 \%)$ \\
\cline { 2 - 4 } Age & Yes & $120(52.8 \%)$ & $94(46.8)$ & $214(49.7 \%)$ \\
\hline \multirow{2}{*}{ Sex } & below 30 & $120(52.2 \%)$ & $106(52.7 \%)$ & $226(52.4 \%)$ \\
\cline { 2 - 4 } & 30 and above & $110(47.8 \%)$ & $95(47.3 \%)$ & $205(47.6 \%$ \\
\hline \multirow{2}{*}{ Family size } & Male & $119(51.7 \%)$ & $94(46.8 \%)$ & $213(49.4 \%)$ \\
\cline { 2 - 4 } & Female & $111(48.3 \%)$ & $107(53.2 \%)$ & $218(50.6 \%)$ \\
\hline \multirow{2}{*}{ Working Place } & $<5$ & $123(53.5 \%)$ & $10250.7 \%$ & $22552.2 \%$ \\
\cline { 2 - 4 } & $>=5$ & $107(46.5 \%)$ & $99(49.3 \%)$ & $206(47.8 \%)$ \\
\hline
\end{tabular}




\begin{tabular}{|l|l|l|l|l|}
\hline \multirow{2}{*}{ Lock down } & No & $122(53.0 \%)$ & $100(49.8 \%)$ & $222(51.5 \%)$ \\
\cline { 2 - 5 } & Yes & $108(47.0 \%)$ & $101(50.2 \%)$ & $209(48.5 \%)$ \\
\hline \multirow{3}{*}{ Safe working environment } & No & $120(52.2 \%)$ & $124(61.7 \%)$ & $244(56.6 \%)$ \\
\cline { 2 - 5 } & Yes & $110(47.8 \%)$ & $77(38.3 \%)$ & $187(43.4 \%)$ \\
\hline Use Transportation & No & $106(46.1 \%)$ & $101(50.2 \%)$ & $207(48.0 \%)$ \\
\cline { 2 - 5 } & Yes & $124(53.9 \%)$ & $100(49.8 \%)$ & $224(52.0 \%)$ \\
\hline \multirow{2}{*}{$\begin{array}{l}\text { Contacting Density } \\
\text { Health Status }\end{array}$} & No & $116(50.4 \%)$ & $86(42.8 \%)$ & $202(46.9 \%)$ \\
\cline { 2 - 5 } & Yes & $114(49.6 \%)$ & $115(57.2 \%)$ & $229(53.1 \%)$ \\
\hline Flight History & No & $115(50.0 \%)$ & $97(48.3 \%)$ & $212(49.2 \%)$ \\
\cline { 2 - 5 } & Yes & $115(50.0 \%)$ & $104(51.7 \%)$ & $219(50.8 \%)$ \\
\hline Total & No & $162(70.4 \%)$ & $169(84.1 \%)$ & $331(76.8 \%)$ \\
\cline { 2 - 5 } & Yes & $68(29.6 \%)$ & $32(15.9 \%)$ & $100(23.2 \%)$ \\
\hline
\end{tabular}

This discovers novel coronavirus disease 2019 will be increased in future. Therefore, creating awareness frequently about the way of protecting infection transmission is critical in different method. Likewise, from the total number of 290 (60.3\%) respondents who work their jobs in office $182(79.1 \%)$ of them didn't care themselves against customers because of poor awareness and other reasons. Similarly, from the total number of $224(52.0 \%)$ respondents who use transportation in their day to day activity 124 (53.9\%) of them have also poor awareness about infection transmission. Finally, from the total number of 100 (23.2\%) of respondents who have flight history and/ or getting foreigners 68 (29.6) have poor awareness about Covid-19 transmission and didn't care themselves.

From the data of geographical distributions of Covid-19 worldwide until April 28, 2020 Figure 1: discovers the infection of Covid-19 increases (at midterm period) in Ethiopia. 


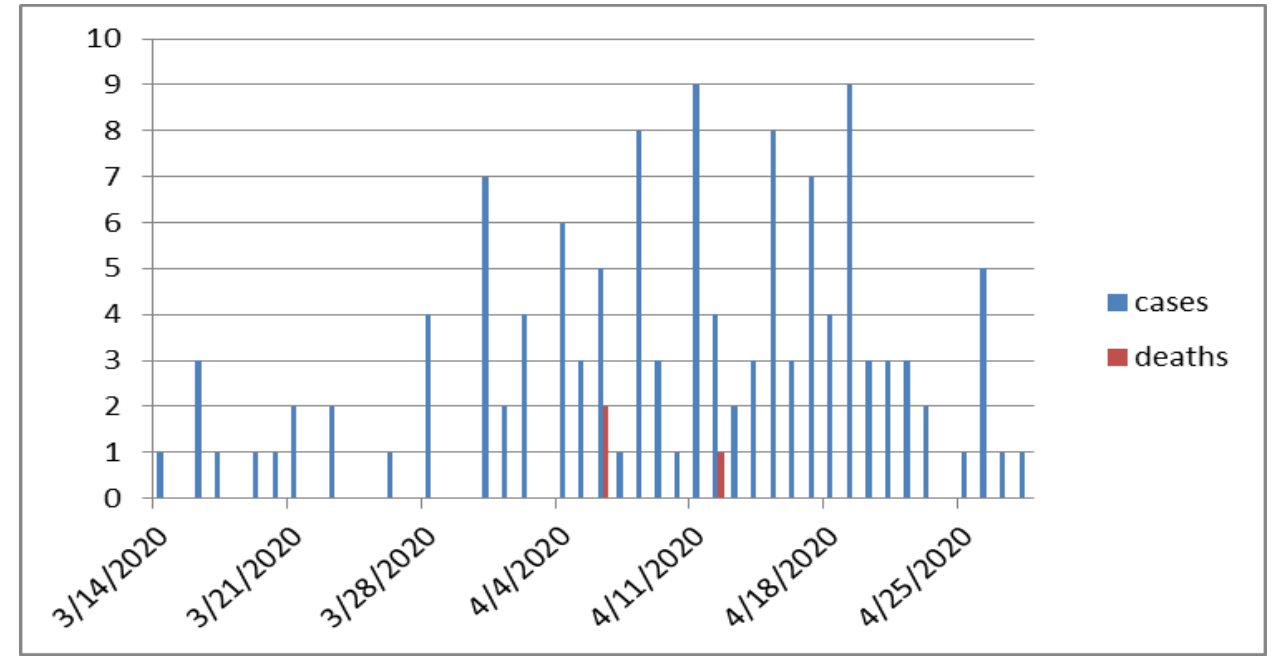

Figure 1: Covid-19 infection Progress in Ethiopia

Figure 2: reports that there is no influential observation in the model fit. Although not visible in this printing, the observations are color coded in the original graphic, with blue indicating a 0 on the response variable and red indicating a 1 .

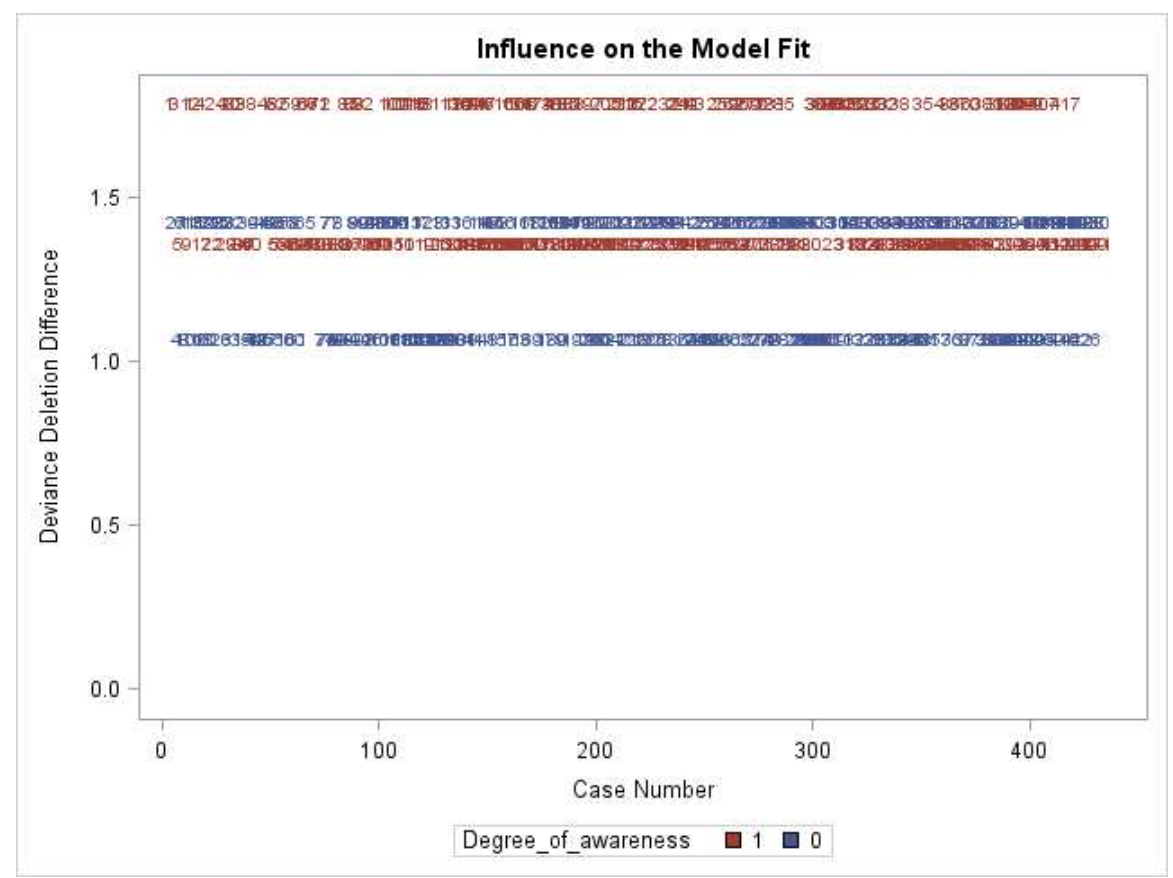

Figure 2: Influence on the model fit

\subsection{Results of Binary Logistic Regression Analysis}

Table 3: Result of Multivariable Binary Logistic Regression Analysis of risk factors Level of awareness (knowledge gap) on Covid-19 transmission method and carefulness

Parameter

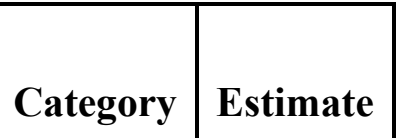

\begin{tabular}{|l|l|} 
& \\
S.E. & Wald
\end{tabular}

\begin{tabular}{|l|c|c|c|}
\multirow{4}{*}{ Sig. } & \multicolumn{3}{|c|}{ Odds Ratio Estimates } \\
\cline { 3 - 4 } & EXP(B) & $95 \%$ C.I. for EXP(B) \\
\cline { 3 - 4 } & & LCL & UCL \\
\hline
\end{tabular}




\begin{tabular}{|l|l|l|c|l|l|l|l|l|}
\hline Intercept & & 0.3567 & 0.1486 & 5.762 & $0.0164^{*}$ & 1.429 & 1.199 & 1.659 \\
\hline $\begin{array}{l}\text { Practicing health care service } \\
\& \text { Physical Distance }\end{array}$ & No & - & - & - & - & - & - & - \\
\hline & Yes & 1.9293 & 0.1976 & 95.329 & $0.0328^{*}$ & 6.885 & 6.765 & 7.005 \\
\hline Working Place & Home & - & - & - & - & - & - & - \\
\hline & Office & 0.1877 & 0.1990 & 0.89 & $0.0357^{*}$ & 1.206 & 0.961 & 1.451 \\
\hline Safe working environment & No & - & - & - & - & - & - & - \\
\hline & Yes & 1.3895 & 0.1962 & 50.156 & $0.0471^{*}$ & 4.013 & 3.768 & 4.258 \\
\hline Use transportation & No & - & - & - & - & - & - & - \\
\hline & Yes & -0.7418 & 0.476 & 2.429 & $0.0379 *$ & 0.476 & 0.176 & 0.776 \\
\hline $\begin{array}{l}\text { Contacting density } \\
\text { population }\end{array}$ & No & - & - & - & - & & - & - \\
\hline & & & & & & & & \\
\hline
\end{tabular}

The likelihood ratio chi-square of 41.4590 with a p-value of 0.0001 tells us that our model as a whole fits significantly better than an empty model. The score and Wald tests are asymptotically equivalent test of the same hypothesis tested by likelihood ratio test, not surprisingly, these test also indicate that the model is statistically significant.

The odds of a person Practicing health care service \& Physical Distance having 6.9\% increase enough awareness about transmission of Covid-19 than the odds of a person don't practicing safe care. Likewise, the odds of workers who work in safe environment have $4 \%$ more likely having enough awareness about transmission of Covid-19 than the odds of persons doing their job in unsafe environment. The odds of respondents use transportation having $47.6 \%$ less likely having enough awareness about transmission of Covid-19 than the odds of respondents who never use transportation. Finally the odds of respondents who have higher rate of contacting density population in their day to day activities have $44.8 \%$ less likely to enough awareness about transmission of Covid-19 than others.

Under a 5\% of level of significance variable such as, Practicing health care service \& Physical Distance, Safe working environment and Contacting density population are statistically significant. 


\subsection{Discussions}

Practicing Health Care Service \& Physical Distance: COVID-19 is transmitted from personto-person via respiratory droplets and fomites during close and unprotected physical contact between an infector and infectee [12]. Based on the above findings human mobility restrictions and social distancing is highly recommended. Therefore encouraging physical distancing measures within the workspace, increased use of email and teleconferences to reduce close contacts, reduced contact between employees and customers, reduced contact between employees, adoption of flexible leave policies and promoting the use of other personal protective countermeasures [9]. By decreasing the frequency and length of social interactions and the physical contacts between individuals leads transmission may therefore be eradicated. Furthermore; extending festivals holidays, protecting community hygiene, washing hand for every 20 seconds, and always covering mouth and nose with tissues or elbow when sneezing or coughing is critical action.

Working Place: Flexible working schedules/ shifts for employees, encourage distance working, working at home, communication behaviors (teleworking, increased use of email and teleconferences) to reduce close contacts, reduce contacts between employees and customers also critical solution against reducing physical contact for transmission of Covid-19 and door-to-door screening [10], [15].

Working Environment: In order to create a safe working environment Use sanitary materials frequently, contact tracing between customers and works, force all customers to wear face mask as well as washing their hand before entering working place, opening window and others are critical [11].

Usage of Transportation: Novel coronavirus disease 2019 infections haven't any vaccination or drug with proven clinical efficacy, although there are several candidates that might be effective in prevention or treatment. Therefore, another critical to eradicate transmission of Covid-19 is traffic schedules/ shifts for drivers, and the control of transportation capacity to reduce the passengers; canceling mass meeting practices. Force all in transportation to wear face mask and sanitizers frequently, getting enough air, reform payment system (mobile and internet banking) [1], [14]. 


\section{Conclusions}

Robust and sufficient awareness, truths about daily disease prevalence and guidance documents (easy controlling method) are frequently adverting to peoples increase their consciousness. Based on the finding we scrutinize and recommend practicing health care service, keeping physical distance, safe working environment, and transportation need critical concern in Addis Ababa. They help us to delay and eradicate outbreaks of Covid-19 for save live of other regions in Ethiopia. Behind this, no need to take time to mobilize individuals and institution for volunteer action (helping poor community members). Another focusing area is door-to-door screening, increasing diagnostic centers and hospital equipment also and need concern by ministry of health.

\section{References}

[1]. Report of the WHO-China Joint Mission on Coronavirus Disease 2019 (COVID-2019). February 16-24, 2020. http://www.who.int/docs/default-source/coronaviruse/who-chinajointmission-on-covid-19-final-report.pdf (Accessed on March 25, 2020).

[2].Hui, D. S.; I. Azhar E.; Madani, T. A.; Ntoumi, F.; Kock, R.; Dar, O.; Ippolito, G.; Mchugh, T. D.; Memish, Z. A.; Drosten, Christian; Zumla, A.; Petersen, E. (February 2020). "The continuing 2019-nCoV epidemic threat of novel coronaviruses to global health-The latest 2019 novel coronavirus outbreak in Wuhan, China". Int J Infect Dis. 91: 264- 66. doi:10.1016/j.ijid.2020.01.009. PMID 31953166

[3].Centers for Disease Control and Prevention. Interim Clinical Guidance for Management of Patients with Confirmed 2019 Novel Coronavirus (2019-nCoV) Infection, Updated February 12, 2020.https://www.cdc.gov/coronavirus/2019-ncov/hcp/clinical-guidanceanagementpatients.html (Accessed on March 26, 2020).

[4].Indian Council of Medical Research (ICMR) 2020

[5].Shrikrushna S. et al. (April 2020). A Review On Corona Virus (Covid-19). World Journal of Pharmaceutical. wjpls, 2020, Vol. 6, Issue 4, 109-115

[6].Worldometer, (2020). COVID-19 Coronavirus Pandemic, 2020 Available at: https://www.worldometers.info/coronavirus/ Accessed on: 2020 March 29

[7]. World Health Organization Director-General's opening remarks at the media briefing on CO VID-19 - 24 February 2020 Available at: 


\title{
https://www.who.int/dg/speeches/detail/who-director-general-s-opening-remarks-at-the-
}

media-briefing-on-covid-19---24-february-2020 (Accessed on February 26, 2020).

[8]. National Comprehensive Covid19 Management Handbook, FMOH, Ethiopia, First edition, April 2020

[9].Lee VJ, Lye DC, Wilder-Smith A. Combination strategies for pandemic influenza response-a systematic review of mathematical modeling studies. BMC medicine. 2009; $7(1): 76$.

[10]. European Centre for Disease Prevention and Control. Outbreak of novel coronavirus disease 2019 (COVID-19): increased transmission globally - fifth update, 2 March 2020. ECDC: Stockholm; 2020.

[11]. WHO research and innovation forum, 2020

[12]. Chan JF, Yuan S, Kok KH, et al. (2020). A familial cluster of pneumonia associated with the 2019 novel coronavirus indicating person-to-person transmission: a study of a family cluster. Lancet 2020; 395:514.

[13]. Huang C, Wang Y, Li X, et al. (2020). Clinical features of patients infected with 2019 novel coronavirus in Wuhan, China. Lancet 2020; 395:497.

[14]. Jin YH, Cai L, Cheng ZS, Cheng H, Deng T, Fan YP, et al. (February 2020). "A rapid advice guideline for the diagnosis and treatment of 2019 novel coronavirus (2019$\mathrm{nCoV}$ ) infected pneumonia (standard version)". Military Medical Research. 7 (1): 4. doi:10.1186/s40779- 020-0233-6. PMC 7003341. PMID 32029004

[15]. Li Q, Guan X, Wu P, et al. (2020). Early Transmission Dynamics in Wuhan, China, of Novel Coronavirus-Infected Pneumonia. N Engl J Med 2020.

[16]. Symptoms of Novel Coronavirus (2019-nCoV)". www.cdc.gov. 10 February 2020. Retrieved 25 March 2020.

\begin{abstract}
Abbreviations
Covid-19: Coronavirus Disease 2012; CDC: Centre for Disease Prevention and Control; $C I$ : Confidence Interval; OR: Odds ratio; SARS: Severe Acute Respiratory Syndrome; SE: Standard Error; $W H O$ : World Health Organization
\end{abstract}

\section{Declarations}

\section{- Ethics approval and consent to participate:}


Ethics approval for this study was not required since the data is secondary and is available in the public domain.

\section{- Consent for publication:}

Not applicable

- Availability of data and materials:

The datasets used and/ or analysed during the current study are available from the corresponding author on reasonable request.

\section{- Competing interests:}

The authors declare that they have no competing interests.

- Funding:

The authors have no support or funding to report.

- Authors' contributions:

GB involved in the inception to design, analysis and interpretation and revises critically the manuscript and edit the manuscript for the final submission, YB involved from the inception to design, acquisition of data, analysis and interpretation, drafting the manuscript. Both authors read and approved the final manuscript.

- Author details

1 Department of Statistics, College of Natural Sciences, Wollo University, Dessie, Ethiopia

2 Department of Statistics, College of Natural and Computational Sciences, Salale University, Fiche, Ethiopia

- Acknowledgments

The authors are grateful to all references and scholars regarding to Covid-19. 
Figures

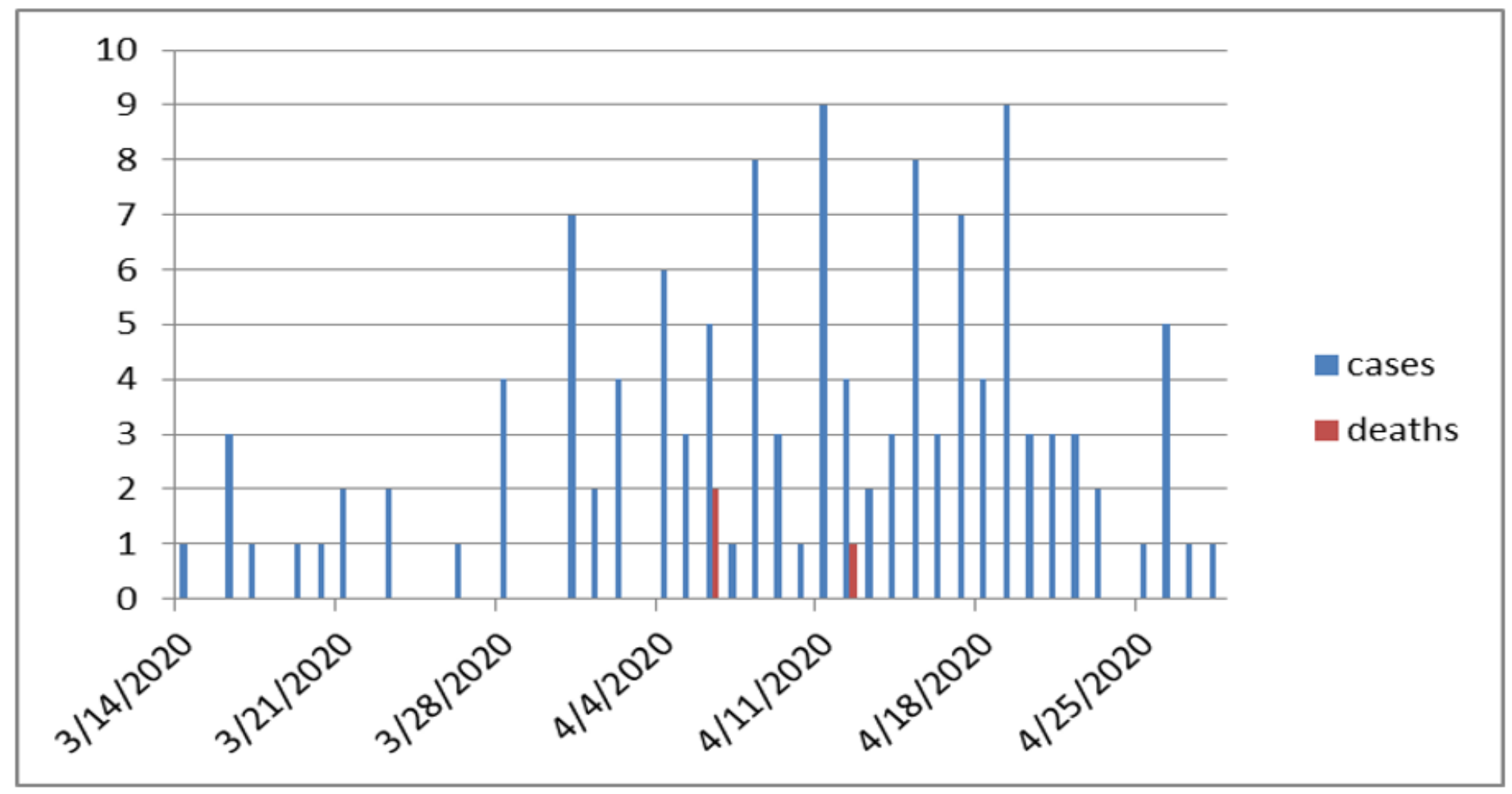

Figure 1

Covid-19 infection Progress in Ethiopia 


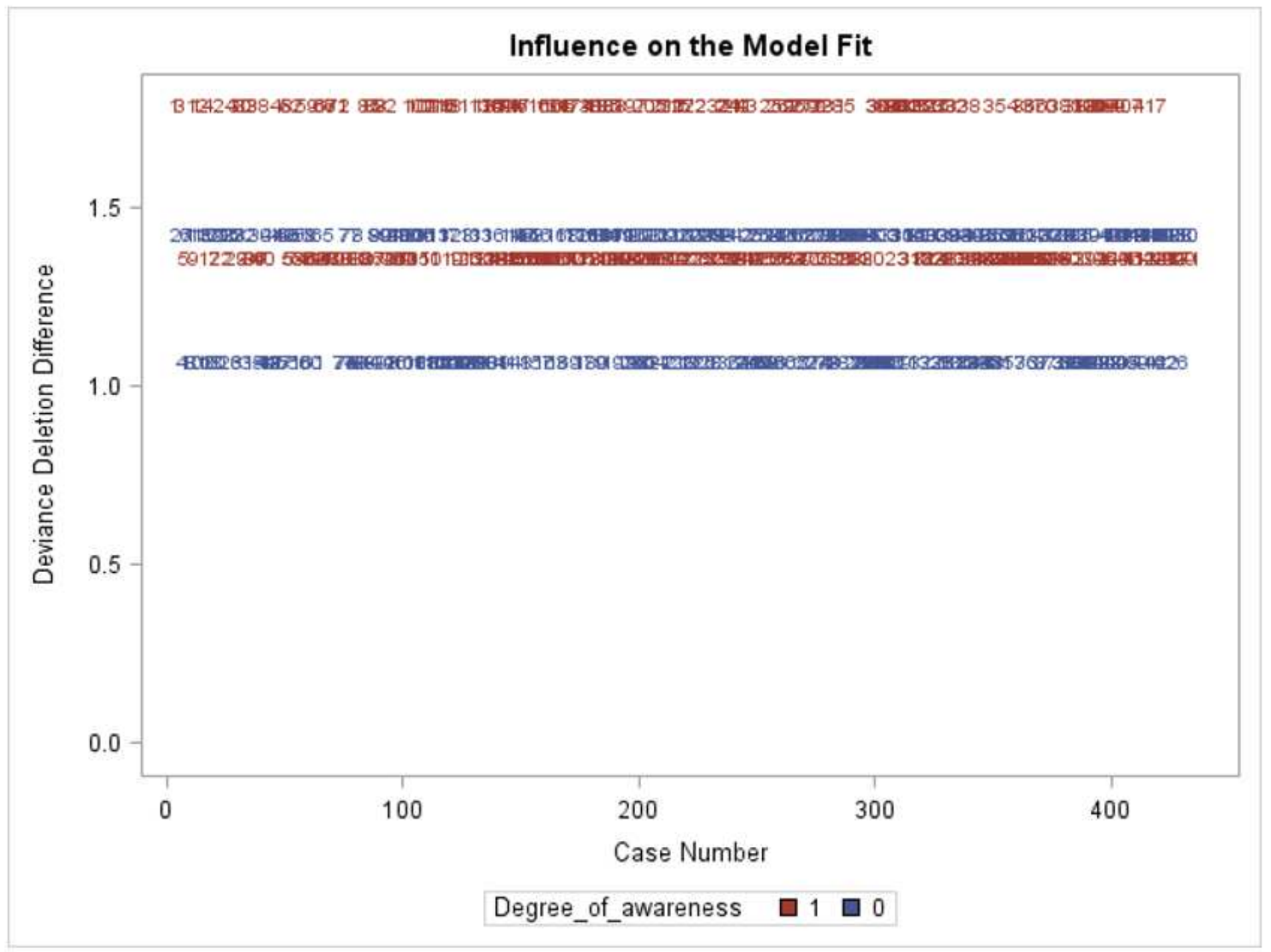

Figure 2

Influence on the model fit 